\title{
Identifying Specific Interpretations and Use of Safety Behaviours in People with Distressing Visual Hallucinations: An Exploratory Study
}

\author{
Robert Dudley \\ Newcastle University and Northumberland, Tyne and Wear Foundation Trust, UK
}

Markku Wood

Norfolk and Waveney Mental Health NHS Foundation Trust

Helen Spencer

Northumberland, Tyne and Wear Foundation Trust, UK

Alison Brabban

Tees, Esk and Wear Valleys NHS Foundation Trust, UK

Urs P. Mosimann

University of Bern, Switzerland

Daniel Collerton

Newcastle University and Northumberland, Tyne and Wear Foundation Trust, UK

\begin{abstract}
Background: Visual hallucinations ( $\mathrm{VH}$ ) are a common experience and can be distressing and disabling, particularly for people suffering from psychotic illness. However, not everyone with visual hallucinations reports the experience to be distressing. Models of $\mathrm{VH}$ propose that appraisals of $\mathrm{VH}$ as a threat to wellbeing and the use of safety seeking behaviours help maintain the distress. Aims: This study investigated whether people with distressing $\mathrm{VH}$ report threat appraisals and use safety behaviours. Method: The study utilized a single group descriptive design, in which 15 participants with psychosis and $\mathrm{VH}$ were asked questions in order to assess the content, distress, appraisals, and behaviours associated with visual
\end{abstract}

Reprint requests to Robert Dudley, Doctorate of Clinical Psychology, Ridley Building, Newcastle University, Newcastle NE1 7RU, UK. E-mail: r.e.j.dudley@ncl.ac.uk An extended version is also available online in the table of contents for this issue: http://journals.cambridge.org/jid_BCP 
hallucinations. Results: People who found visual hallucinations distressing $(n=13)$ held negative appraisals about those hallucinations and specifically saw them as a threat to their physical or psychological wellbeing. They also engaged in safety seeking behaviours that were logically related to the appraisal and served to maintain the distress. Conclusions: People with distressing VH regard them as a threat to their wellbeing and use safety seeking behaviours as a result of this perceived threat. These key processes are potential targets for treatments that will alleviate the distress associated with $\mathrm{VH}$.

Keywords: Psychosis, safety seeking behaviours, visual hallucinations.

\section{Introduction}

Visual hallucinations (VH) are common in people with psychosis where they are associated with particular distress and disability (Mueser, Bellack and Brady, 1990). To date there has been scant research into $\mathrm{VH}$. The work so far indicates that the appraisal of the $\mathrm{VH}$ is important in understanding distress. Gauntlett-Gilbert and Kuipers (2005) found that an individual's appraisal did not simply follow on from the content, frequency or duration of the $\mathrm{VH}$ and that if the individual's appraisal of this experience was negative then this directly predicted distress.

Collerton and Dudley (2004) argued that the appraisal of the visual experience was central to understanding the distress associated with VH. Specifically, it was proposed that people would appraise the visual experience as a threat to their physical or psychological wellbeing, and that they would use Safety Seeking Behaviours (SSBs) to help manage this distress much like people with other emotional and psychotic symptoms do.

The current research is intended to inform two key elements of the Collerton and Dudley (2004) model and by doing so provide a greater understanding of the psychological processes involved in the experience of distressing VH. First, the research was designed to study the specific appraisals of $\mathrm{VH}$. Previous research into $\mathrm{VH}$ has indicated that appraisal is important but has not specified whether it is perceived as a threat to wellbeing. The second aim was to investigate the use of SSBs by people with $\mathrm{VH}$. If people appraised their experiences as a threat to wellbeing then it would be expected that they would take steps to prevent the feared outcome from happening and use SSBs that are logically related to the appraisal.

\section{Method}

Design

A single group descriptive design was employed.

\section{Participants}

Participants were recruited from local Early Intervention for Psychosis (EIP) services. The inclusion criteria were:

- Experiencing complex visual hallucinations

- Aged between 16 and 38 (the upper age range of EIP services), with a history of psychotic experiences

- Capacity to give informed consent 
The exclusion criteria were:

- History of significant substance abuse in the past 6 months, or any use of hallucinogens at the time of experiencing the visual hallucination

- Visual hallucinations that were the result of organic disorders or injury

Twenty-five people were approached to participate in the study; 6 declined and 3 agreed to participate but did not attend scheduled meetings. The 16 participants were predominantly young men (10 males; 6 females, mean age of $25, S D=4.31)$. The mean age of onset of psychosis was 21 years $(S D=4.65)$. Fifteen $(94 \%)$ were diagnosed as suffering from psychosis and one (6\%) from schizophrenia. Two (13\%) were inpatients at the time of participation. Fifteen $(94 \%)$ were prescribed antipsychotic medication and one $(6 \%)$ was not. During testing one participant revealed drug usage at the time of experiencing the $\mathrm{VH}$. Consequently, 15 participants were included in the analysis.

\section{Measures}

Three structured interviews were utilized to determine: i) the presence of recurrent complex visual hallucinations; ii) the use of illicit substances; and iii) the specific content, affect, appraisals and behaviours related to the visual hallucinations.

The participants completed the North East Visual Hallucinations Interview (NEVHI 21; Mosimann et al., 2007), which consists of 21 items relating to different indices of visual hallucinations. It is a validated measure, specific to visual hallucinations and was used to confirm the presence of complex visual hallucinations. ${ }^{1}$

The Drake Substance Misuse Scale (DSMS; Drake, Mueser and McHugo, 1996) is an 11-item interview-based measure of substance use. None of the participants reported using hallucinogens in the last 6 months; four participants had used hallucinogens in their lifetime. However, the $\mathrm{VH}$ were reported long after and independent of the last use of hallucinogens.

The third measure, the Appraisals and Reactions to Visual Hallucinations Interview (ARVHI) was devised by the authors (copy available from corresponding author), to gain specific information about the content of the $\mathrm{VH}$, the distress associated with seeing the vision, and the appraisals, feared outcomes and use of SSBs.

Initially, the interview asks about the content of the visual experience, as well as whether the person believes that the vision has malevolent or benevolent intentions. The person is then asked to rate how distressed (on a scale of 0-10) the person feels at the moment that they are actually seeing the vision. To better understand the appraisals of the distressing $\mathrm{VH}$ the ARVHI asked "What is the worst thing that could happen as a result of seeing the VH?" The individual was also asked to rate how much he or she believes the negative event will occur on a scale of $0-10$, ( 0 being "not at all" believed to 10 being "completely" believed).

In order to address the issue of whether participants use SSB they were asked what they did when they saw the vision and how often they relied on this behaviour. Participants identified the most highly used coping behaviour and were asked "what would happen if you did not

\footnotetext{
${ }^{1}$ Visual hallucinations are commonly classified into two types based on their phenomenology: simple visual hallucinations that are "unformed" images (i.e. flashes of light, sparks); and complex visual hallucinations or "formed" images (i.e. people, animals, inanimate objects) (Mosimann et al., 2007).
} 
use this behaviour?" which helps to identify intention and perceived consequences from the person's perspective, which are key to the identification of SSBs (Thwaites and Freeston, 2005).

\section{Procedure}

Participants were provided with an information sheet describing the study and written consent was given by all participants. Participants completed the NEVHI, DSMS then the ARVHI.

\section{Results}

\section{Data analysis strategy}

First, the VHs were classified according to whether or not they were distressing. This classification was achieved by considering the beliefs about the vision (as positive or negative) and whether the person reported high levels of distress at the time of seeing the visual experience. The subsequent questions about appraisals and response to VHs were only considered in relation to distressing VHs, so it was vital to ensure that these were identified. The data referring to the question of whether appraisals of the distressing VH represent a threat to psychological or physical wellbeing and the relationship between the appraisals and the response were presented descriptively.

\section{Content and beliefs about visions}

All the participants experienced complex VHs. Fourteen (93.38\%) participants saw a "life like" human figure with one $(6.67 \%)$ seeing a life like humanoid hand puppet (Mr. Punch). Two (13.34\%) participants held positive beliefs about the hallucination, whereas $11(73.37 \%)$ held negative beliefs. Two (13.34\%) participants had both positive and negative beliefs at times; when asked directly, however, they considered the experiences as predominantly negative.

The 13 participants who held negative beliefs about VH experience reported high levels of negative affect (a mean score of $7.46 S D=2.54$, on a $0-10$ scale) at the time of seeing their visions. A small sample size meant that no formal analysis was undertaken of the two participants who interpreted the $\mathrm{VH}$ as positive and their data is not included further.

\section{Exploration of specific appraisals}

Having identified the content, perceived beliefs about and affect associated with the distressing VHs, it is next necessary to determine whether the specific appraisals represent a threat to psychological or physical wellbeing. Table 1 reports the participants' perceived threat in seeing the $\mathrm{VH}$, and their degree of conviction in the threat. These results were taken from the ARVHI which asked, "What is the worst thing that could happen as a result of seeing the VH?". Table 1 also details the extent to which the individual believes the negative event will occur ( 0 being "not at all" believed to 10 being "completely" believed).

All of the participants identified a specific perceived threat associated with the VH. The potential for the threat to come to fruition was held with strong conviction (mean $=9.15, S D$ 
Table 1. Characteristics and perceived threat of the visual hallucination

\begin{tabular}{|c|c|c|c|c|c|c|c|}
\hline Participant & Content of VH & $\begin{array}{c}\text { Participant } \\
\text { interpretation of } \\
\text { VH }\end{array}$ & $\begin{array}{c}\text { Appraisal of the } \\
\text { VH }\end{array}$ & $\begin{array}{l}\text { How much do you } \\
\text { believe this? } 0 \text { (not } \\
\text { at all) to } 10 \\
\text { (completely) }\end{array}$ & $\begin{array}{l}\text { Most highly used } \\
\text { behaviour reported } \\
\text { by the participant }\end{array}$ & $\begin{array}{c}\text { Perceived } \\
\text { consequence of not } \\
\text { engaging in } \\
\text { behaviour }\end{array}$ & $\begin{array}{l}\text { How much } \\
\text { do you } \\
\text { believe this? } \\
\quad(0-10)\end{array}$ \\
\hline 1 & $\begin{array}{l}\text { Saw her deceased } \\
\text { grandmother and } \\
\text { grandfather - } \\
\text { they were } \\
\text { pleasant and } \\
\text { gave advice }\end{array}$ & Positive & & & & & \\
\hline 2 & $\begin{array}{l}\text { Ghosts - mostly } \\
\text { women - can } \\
\text { appear in colour } \\
\text { or appear to be } \\
\text { transparent or } \\
\text { "see through" - } \\
\text { tell future and } \\
\text { compli- } \\
\text { ment/advise } \\
\text { him }\end{array}$ & Positive & & & & & \\
\hline 3 & $\begin{array}{l}\text { Jim - a gangster } \\
\text { drilling in to } \\
\text { people's heads }\end{array}$ & Negative & $\begin{array}{l}\text { I will freak out in } \\
\text { public }\end{array}$ & 5 & Ignore & $\begin{array}{l}\text { Jim will continue } \\
\text { to kill people. I } \\
\text { will also be } \\
\text { stressed and } \\
\text { irritated }\end{array}$ & 10 \\
\hline 4 & $\begin{array}{l}\text { A man hanging } \\
\text { from a noose in } \\
\text { a tree - the man } \\
\text { is dead }\end{array}$ & Negative & $\begin{array}{l}\text { I will harm myself } \\
\text { and go to a } \\
\text { mental hospital }\end{array}$ & 10 & Talk to friends & $\begin{array}{l}\text { I would feel really } \\
\text { bad }\end{array}$ & 10 \\
\hline
\end{tabular}


Table 1. Continued

\begin{tabular}{|c|c|c|c|c|c|c|c|}
\hline Participant & Content of VH & $\begin{array}{c}\text { Participant } \\
\text { interpretation of } \\
\text { VH }\end{array}$ & $\begin{array}{l}\text { Appraisal of the } \\
\text { VH }\end{array}$ & $\begin{array}{l}\text { How much do you } \\
\text { believe this? } 0 \text { (not } \\
\text { at all) to } 10 \\
\text { (completely) }\end{array}$ & $\begin{array}{l}\text { Most highly used } \\
\text { behaviour reported } \\
\text { by the participant }\end{array}$ & $\begin{array}{c}\text { Perceived } \\
\text { consequence of not } \\
\text { engaging in } \\
\text { behaviour }\end{array}$ & $\begin{array}{l}\text { How much } \\
\text { do you } \\
\text { believe this? } \\
\quad(0-10)\end{array}$ \\
\hline 5 & $\begin{array}{l}\text { Jane - girl that } \\
\text { looks like me - } \\
\text { is critical of me } \\
\text { - tells me to } \\
\text { harm myself - } \\
\text { gets angry and } \\
\text { makes threats }\end{array}$ & $\begin{array}{l}\text { Negative with } \\
\text { some positive } \\
\text { features }\end{array}$ & $\begin{array}{l}\text { I will go back to } \\
\text { self harm }\end{array}$ & 10 & Play computer & $\begin{array}{l}\text { It would get worse } \\
\text { - until I did what } \\
\text { she told me to do }\end{array}$ & 8 \\
\hline 6 & $\begin{array}{l}\text { Peter's head } \\
\text { (abusive } \\
\text { ex-boyfriend)- } \\
\text { threatening to } \\
\text { hurt my father }\end{array}$ & Negative & $\begin{array}{l}\text { I will go to a } \\
\text { mental home }\end{array}$ & 10 & $\begin{array}{l}\text { Attacked VH - } \\
\text { shouted - } \\
\text { punched }\end{array}$ & $\begin{array}{l}\text { More frightened } \\
\text { and upset }\end{array}$ & 10 \\
\hline 7 & $\begin{array}{l}\text { Aggressive } \\
\text { fighting "shadow } \\
\text { man" }\end{array}$ & Negative & $\begin{array}{l}\text { I will throw things } \\
\text { and end up with } \\
\text { a hospital } \\
\text { admission }\end{array}$ & 10 & $\begin{array}{l}\text { Distract myself - } \\
\text { watch TV - play } \\
\text { computer }\end{array}$ & $\begin{array}{l}\text { Get upset - self } \\
\text { harm }\end{array}$ & 10 \\
\hline 8 & $\begin{array}{l}\text { TV presenter } \\
\text { talking } \\
\text { aggressively and } \\
\text { threateningly }\end{array}$ & Negative & $\begin{array}{l}\text { I will harm myself } \\
\text { or someone else }\end{array}$ & 10 & $\begin{array}{l}\text { Take a walk in the } \\
\text { fresh air }\end{array}$ & $\begin{array}{l}\text { Very bad - hurt } \\
\text { myself or } \\
\text { someone else }\end{array}$ & 10 \\
\hline 9 & $\begin{array}{l}\text { Puppet Punch, } \\
\text { "tells me to kill } \\
\text { myself" }\end{array}$ & Negative & I will kill myself & 10 & $\begin{array}{l}\text { Clean } \\
\text { "obsessively", }\end{array}$ & $\begin{array}{l}\text { Would kill myself } \\
\text { and go crazy }\end{array}$ & 10 \\
\hline
\end{tabular}




\begin{tabular}{|c|c|c|c|c|c|c|c|}
\hline 10 & $\begin{array}{l}\text { Shadow person, } \\
\text { standing over } \\
\text { me/in the corner } \\
\text { of the room }\end{array}$ & Negative & I would die & 10 & $\begin{array}{l}\text { Say a mantra - } \\
\text { pray over and } \\
\text { over }\end{array}$ & $\begin{array}{l}\text { I would lose it and } \\
\text { jump out of a } \\
\text { window }\end{array}$ & 8 \\
\hline 11 & $\begin{array}{l}\text { Shadow man/on } \\
\text { the cupboard, } \\
\text { ready to pounce }\end{array}$ & Negative & $\begin{array}{l}\text { I will be locked up } \\
\text { in hospital }\end{array}$ & 10 & $\begin{array}{l}\text { Ignore him, try } \\
\text { look away }\end{array}$ & $\begin{array}{l}\text { Get distressed } \\
\text { "really do my } \\
\text { head in" }\end{array}$ & 7 \\
\hline 12 & Shadow man & Negative & $\begin{array}{l}\text { I would "Go } \\
\text { mental" }\end{array}$ & 6 & $\begin{array}{l}\text { Close eyes and } \\
\text { hide under the } \\
\text { covers }\end{array}$ & $\begin{array}{l}\text { Never tried, it is } \\
\text { too risky! I } \\
\text { would be too } \\
\text { frightened }\end{array}$ & 10 \\
\hline 13 & Man with gun & Negative & I will harm myself & 10 & Pray & I would feel awful & 10 \\
\hline 14 & $\begin{array}{l}\text { Grandfather - } \\
\text { sometimes tells } \\
\text { me to kill myself }\end{array}$ & $\begin{array}{l}\text { Negative with } \\
\text { some positive } \\
\text { features }\end{array}$ & $\begin{array}{l}\text { It will bring on a } \\
\text { psychotic } \\
\text { episode }\end{array}$ & 10 & $\begin{array}{l}\text { Accept it is } \\
\text { happening }\end{array}$ & $\begin{array}{l}\text { Would get } \\
\text { stressed, } \\
\text { panicky, and } \\
\text { paranoid }\end{array}$ & 10 \\
\hline 15 & $\begin{array}{l}\text { Marco - the insane } \\
\text { vampire }\end{array}$ & Negative & $\begin{array}{l}\text { It will push me } \\
\text { over the edge } \\
\text { and I will } \\
\text { experience } \\
\text { another } \\
\text { psychotic } \\
\text { episode }\end{array}$ & 8 & Watch TV & Would get upset & 10 \\
\hline
\end{tabular}


1.72). A threat to psychological wellbeing was reported by most of the participants but for a few $(n=6)$ the worst aspect of seeing a vision was that it represented a threat to the physical wellbeing. With regards therefore to the first question of whether people with distressing $\mathrm{VH}$ hold negative appraisals of these experiences and see them as a threat to wellbeing the results are seemingly supportive of this view.

\section{Use of safety seeking behaviours}

The next section considers whether people with negative appraisals of distressing VH engage in SSBs that are logically related to the appraisal and whether the behaviour satisfies the criteria for a SSB. To this end participants were asked to identify the most highly used coping behaviour and were asked "what would happen if you did not use the behaviour?", which helps to identify intention and perceived consequences from the person's perspective. Table 1 reports the extent they believe in the feared consequence of not using the behaviour (with 0 being "not at all" and 10 being "completely" believe).

It is apparent that the actual form of each of the behaviours is varied. However, it does seem that the intention of the behaviours is to reduce the likelihood of the perceived threat being realized and that it is believed strongly that this is necessary to act in this way. The high conviction ratings (mean score of 9.46, SD 1.05) suggested that the participants believe that the feared outcome would happen if they did not engage in the behaviour.

Overall the results indicate that participants engaged in SSBs that were logically related to the negative beliefs/appraisals and hence were consistent with the second proposal of the Collerton and Dudley (2004) model.

\section{Discussion}

This study examined the phenomenology of distressing visual hallucinations. Most of the participants in the study found their visions distressing (13/15). This group negatively appraised the visions. A common perceived threat from the vision was threat to mind and/or psychological wellbeing. Often people thought that the vision meant that they could go mad, or end up having to go to hospital. Six of the participants perceived the vision as mainly a threat to their physical wellbeing. Participants tried to cope with the perceived threat from the vision and the coping behaviours could be classed as SSBs according to the Thwaites and Freeston (2005) definition.

These findings highlight areas for possible therapeutic intervention with individuals who experience distressing VH. As with interventions for auditory hallucinations and anxiety disorders, ways to help people reduce and stop the use of SSBs may help reduce distressing appraisals.

The findings should be interpreted with caution. It should be noted that the ARVHI's reliability and validity has yet to be established. Moreover, it may be difficult to disentangle whether seeing the vision is a fear of relapse or a fear of the vision itself.

The study closely followed literature on auditory hallucinations and anxiety disorders, giving it a strong theoretical base from which to explore the research question. However, it may be a weakness in that it may not be appropriate to apply the theory from these disorders to the phenomena of visual hallucinations. 


\section{References}

Collerton, D. and Dudley, R. (2004). A cognitive behavioural framework for the treatment of distressing visual hallucinations in older people. Behavioural and Cognitive Psychotherapy, 32, 443445.

Drake, R. E., Mueser, K. T. and McHugo, G. J. (1996). Clinician rating scales: Alcohol Use Scale (AUS), Drug Use Scale (DUS), and Substance Abuse Treatment Scale (SATS). In L. I. Sederer and B. Dickey (Eds.), Outcomes Assessment in Clinical Practice. Baltimore: Williams and Wilkins.

Gauntlett-Gilbert, J. and Kuipers, E. (2005). Visual hallucinations in psychiatric conditions: appraisals and their relationship to distress. British Journal of Clinical Psychology, 44, 77-87.

Mosimann, U. P., Collerton, D., Dudley, R., Meyer, T. D., Graham, G., Dean, J. L., et al. (2007). A semi-structured interview to assess visual hallucinations in older people. International Journal of Geriatric Psychiatry, 22, 1-7.

Mueser, K. T., Bellack, A. S. and Brady, E. U. (1990). Hallucinations in schizophrenia. Acta Psychiatrica Scandanavica, 82, 26-29.

Thwaites, R. and Freeston, M. (2005). Safety-seeking behaviours: fact or function? How can we clinically differentiate between safety behaviours and adaptive coping strategies across anxiety disorders? Behavioural and Cognitive Psychotherapy, 33, 177-188. 